person in a table of disease incidence, the patient whose data are piled into a study of this or that disease. Just as Vesalius put his skeletons in a landscape to remind his readers of the person who was, of the humanity in the medicine, LoCurto and Outcault remind us of the persons whose lives are hidden in the maps of mortality and morbidity that local, state, national, and world agencies disseminate in bewildering abundance. These images stand as a corrective to the anonymity of our statistics and our maps in which the tragedy and triumph of individuals with disease disappear.

\section{Tom Koch PhD}

Vancouver, BC

\section{REFERENCES}

I. Saunders J B, O'Malley DD. The illustrations from the works of Andreas Vesalius of Brussels. New York: Dover Publications; I950. Available: http: //vesalius.northwestern.edu/ (accessed 2007 Nov 4).

2. Wood D. Some things Lilla LoCurto and William Outcault have to say about maps. Cartographic Perspectives 2007;56:8-8.

3. Anker S. Face value: plastic surgery and transfor mation art. Science and the City. New York: The New York Academy of Science; 2005. Available: http://www.nyas.org/snc/gallery.asp? exhibitID=I4 (accessed 2007 Nov 4).

Tom Koch is the author of 14 books including Cartographies of Disease: Maps, Mapping and Medicine.

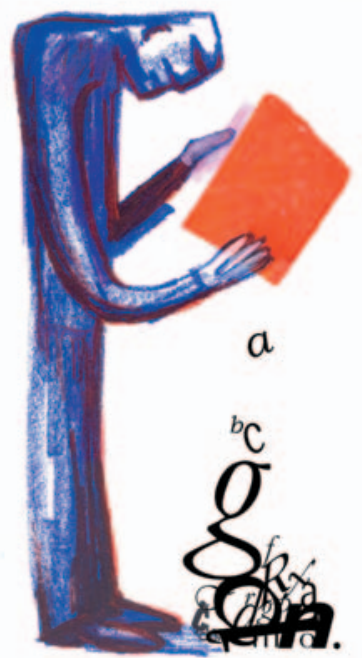

\title{
Historic operating room a monument to the advent of antisepsis
}

B uried deep within the heart of Royal Jubilee Hospital in Victoria, British Columbia, a small, unassuming brick building stands empty and alone. But this century-old operating room marks a milestone in medical history, as the sole surviving facility of its kind in Canada. Victoria's doctors are well aware of its importance and, over the years, have fought for its preservation, applauded its designation as a National Historic Site and are now determined to keep its heritage alive.

To truly appreciate this unique operating room's place in history, one must picture its origins in Victoria over 100 years ago. Starting as a Hudson's Bay Company fur-trading post in 1843 , Victoria had grown in 5 short decades into a city, provincial capital and partner in Confederation. Medical care developed along with the expanding population. Victoria's first hospital - a cottage in the downtown core — was replaced by several larger facilities, but soon they too were woefully inadequate.

In the mid-I88os, a group headed by Dr. John Chapman Davie Jr. lobbied for a new hospital. Davie designed and planned a "pavilion style" facility — all on one level, with separate but interconnected structures - and in 1890 , the Provincial Royal Jubilee Hospital started to take shape.

Six years later, the hospital received an unexpected windfall in the form of a bequest from the estate of Joseph Pemberton, the former British Columbia colonial surveyor who was felled by a massive heart attack while riding his horse not far from the hospital gates. Davie spoke out strongly in favour of using the bequest for an operating room. After much discussion, the hospital board agreed to put Pemberton's $\$ 3500$ gift toward a surgical centre that would embrace Dr. Joseph Lister's principles of antisepsis.

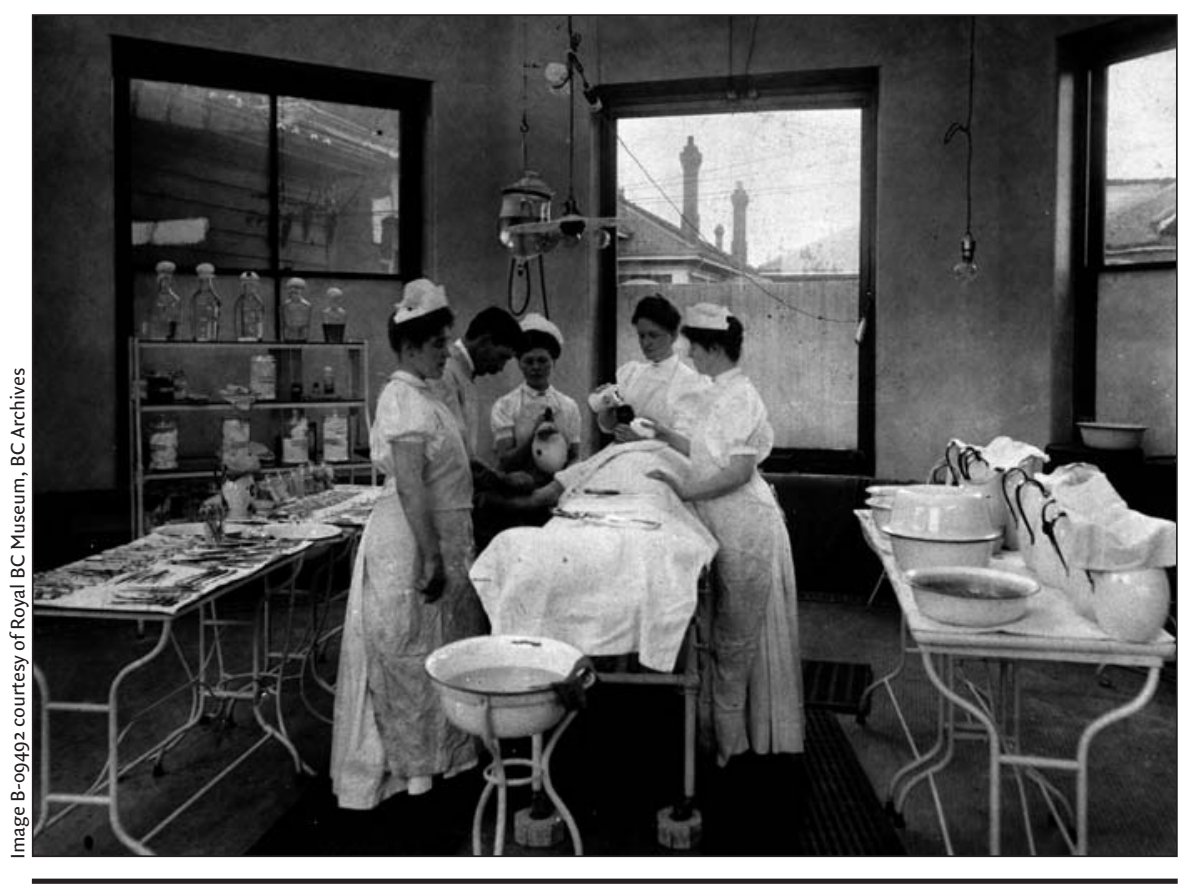

The Pemberton Memorial Operating Room was designated as a National Historic Site of Canada in 2006 due to its importance in representing a transition in surgery and the evolution of the scientific hospital. This photograph was taken around 1900, before masks, gloves and hair coverings were commonly used. 
Lister was truly a legend in his own lifetime. Qualifying as a doctor in London in 1852 , he became a Fellow of the Royal College of Surgeons that same year, then moved to Edinburgh to build on his surgical experience. While there, he perfected the techniques of antisepsis that would subsequently save thousands of lives.

Before Lister's time, surgical procedures were often a deadly affair. In I86os Britain, almost half of all patients undergoing major surgery died in the days that followed. Wound infections and gangrene were blamed on "bad air." It was French chemist and bacteriologist Louis Pasteur who first recognized the significance of air-borne organisms in the spoilage of products such as milk or wine and in certain human diseases. Lister took Pasteur's theories a step further, by surmising that those same organisms, if given access to a person's body via a surgical wound, would end up infecting it.

While Pasteur destroyed germs by heat, Lister concentrated on cleanliness. He washed his hands frequently and insisted on laundered towels. Using carbolic acid as an agent of antisepsis, he sterilized his instruments, soaked wound dressings, and sprayed the substance liberally around the operating area. His patients survived, although the caustic effects of carbolic - numb skin, cracked nails and sore lungs - soon caused Lister and others to abandon it in favour of other antiseptic agents.

News of Lister's work spread quickly, although many surgeons were slow to accept his ideas. Not so Brockville-born Dr. Archibald Edward Malloch, who studied and worked with Lister in Scotland in the

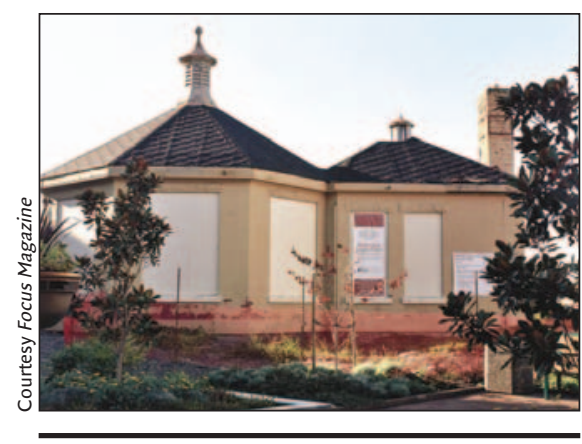

The Pemberton Memorial Operating Theatre will soon be restored, then transformed into a museum and educational resource. late I86os. Upon returning to Hamilton, Malloch became the first surgeon in North America to openly embrace his techniques. On the other side of the continent, Davie, who followed Lister's teachings while on sabbatical in Europe, was an equally fervent follower.

The Pemberton Memorial Operating Room, which opened in 1896 , was the first such facility north of San Francisco, California, and west of Winnipeg, Manitoba, to accommodate Lister's antisepsis techniques. Designed by Davie himself, the building was octagonal in shape and almost free-standing, being accessed from the hospital by a I5-metre long corridor. Its stone foundation supported a concrete floor topped with mosaic ceramic tile. Brick walls covered with painted plaster surrounded a modest space that could accommodate only the surgical staff and the patient, with no room for observers. A sterilizing room was attached at its north end.

In 1897 , Lister (who was, by then, a Lord) visited Vancouver Island after attending a medical meeting in Montréal. Victoria's medical community turned out in force, and Davie headed the group that escorted its prestigious guest by horsedrawn carriage to the Royal Jubilee. Lister was favourably impressed by the new operating facility, and recommended it be augmented by a post-anesthetic recovery room, which was duly added.

In 1900 alone, more than 200 operations were performed in the building. Twenty-five years later, new operating rooms were built and the Pemberton Memorial Operating Room became home to, in turn, the radiography department, the cancer agency and the medical records department. The last of the original hospital buildings was demolished in 1990. Denying the Victoria Medical Society's request for heritage status for the old operating room, the hospital agreed instead to plan around it. The Pemberton Memorial Operating Room, unused by this time, was left empty but intact.

In 1995, The Pemberton Memorial Operating Room received heritage designation from Victoria City Council, and federal government historians confirmed its cultural importance as representing a transition in surgery and the evolution of the scientific hospital. In

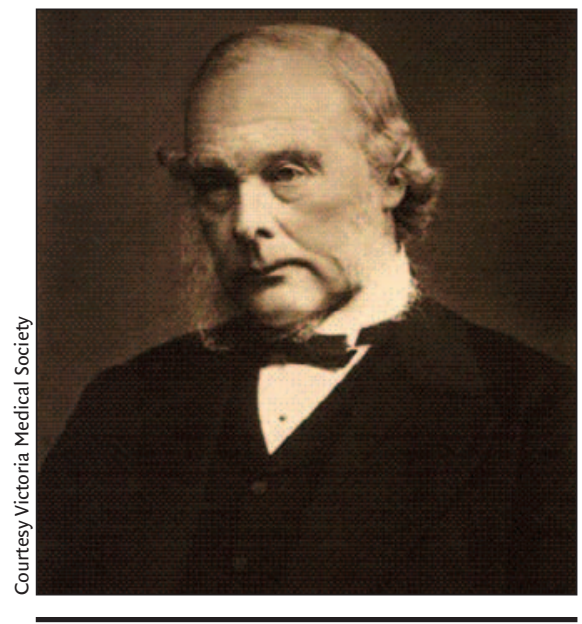

Lord Joseph Lister, 1827-1912, discovered and introduced the principles of antisepsis to medicine.

2006 it was named a National Historic Site of Canada.

The Victoria Medical Heritage Society, a charitable arm of the Victoria Medical Society, was formed in 2004 to provide for the Pemberton Memorial Operating Room's restoration and rehabilitation. Thus far, it has received generous support from Victoria's medical community, the Heritage Legacy Fund of British Columbia's Conservation Program, and the Victoria Foundation. The first phase of the project, restoration of the roof, began last fall.

The idea is to restore the Pemberton Memorial Operating Room, then transform it into a museum and educational resource, including an archives, a history of medicine library and collection of artifacts. Rotating displays might include the evolution of hospitals from charitable institutions for the poor into the present-day high-tech health centres for all, Pasteur and Lister's innovative use of antisepsis techniques and today's continuing focus on infection control. Fittingly, the ultimate aim is for the Pemberton Memorial Operating Room to become a centre for active examination of and discussion around advances in patient care.

\section{Danda Humphreys RN}

Author and historian

Victoria, BC

Danda Humphreys is a former managing editor of the BC Medical Journal. 